\title{
Seroprevalence of Helicobacter pylori infection among Children attending selected Hospitals in Keffi, Nigeria
}

\author{
Janet J Adedoyin $^{1 *}$, Ishaleku David ${ }^{1}$ \\ ${ }^{1}$ Department of Microbiology, Nasarawa State University. P. M. B. 1022, Keffi, Nigeria
}

Received Date: September 02, 2020; Accepted Date: September 08, 2020 Published Date: September 17, 2020

Corresponding author: Janet J Adedoyin, Department of Microbiology, Nasarawa State University. P. M. B. 1022, Keffi, Nigeria. Email: janeadedoyin2014@gmail.com

\section{Abstract}

Helicobacter pylori (H. pylori) infection historically happens in early childhood, particularly in low- and middleincome countries. Most carriers of these bacteria are usually asymptomatic. This study was conducted to determine the seroprevalence of Helicobacter pylori infection among children attending selected hospitals in Keffi metropolis between April and June 2015. Two milliliters ( $2 \mathrm{ml})$ of blood sample was collected from one hundred randomly selected children of age 0-15years via venipuncture. The blood samples were serologically analyzed using immuno-chromatographic rapid test kits (Global). Out of the 100 samples examined, only $6.0 \%$ of the children were seropositive for $\mathrm{H}$. pylori infection. The prevalence of $H$. pylori infection was higher in female $(7.1 \%)$ than in male $(4.6 \%)$ and rose with increase in ages of the children. Statistically there was no significant difference $(p>0.05)$ with respect to gender and age. There was also no significant difference when $H$. pylori infection was associated with socio-demographic characteristics and predisposing factors such as sources of drinking water $(\mathrm{p}=0.9875)$, type of toilet $(\mathrm{p}=0.7165)$, hand washing behaviour $(\mathrm{p}=0.5049)$ and eating habit $(\mathrm{p}=0.9936)$. The comparison between symptomatic (14.3\%) and asymptomatic (5.4\%) children was also insignificant $(\mathrm{p}=0.9056)$. The results of the study further revealed that there was an increase in awareness of hygienic practices. Improved sanitary conditions and proper public health Education on the possible mode of transmission of the bacteria is still recommended for further eradication.
Keywords: Asymptomatic; Children; Helicobacter pylori; Prevalence; Symptomatic

\section{Introduction}

Helicobacter pylori is a helix shaped, gram negative, microaerophilic bacteria that is a prevalent etiological agent for chronic gastritis. H. pylori were originally referred to as Campylobacter pylori and was first isolated in 1983 by two Australian scientists, Robin Warren and Barry Marshall [1]. It is reported to be preponderate in most developing countries and has affected half of the world's population [2, 3]. In 1994, the World Health Organization (WHO) classified $H$. pylori as a class 1 carcinogen $[4,5]$. The bacteria have since been treated as a significant risk factor for development of gastric and duodenal ulcers, mucosa lymphoid tissue lymphoma (MALT lymphoma) and gastric adenocarcinoma [6, 7].

Although $H$. pylori infection acquisition occurs in early childhood, most of its carriers are asymptomatic and could bear the bacteria within the gastric mucosa for their entire lifetime. Malnutrition and growth faltering have been associated with the bacterium infection in children [8]. The prevalence of $H$. pylori varies among populations and it is higher in industrialized countries than developing ones. Although the route of infection transfer is still notional, environmental factors are believed to affect its development in different populations $[\mathbf{2 , 9}$, 10].

Both invasive and non-invasive tests can be used to detect the presence of $H$. pylori infection in a person. While the 
former requires endoscopy, the later involves rather nonendoscopic methods; serology test, breath test and stool test. Serological tests have been used by some researchers in Nigeria as well as other countries, to report the prevalence of H. pylori infections in children. Their results showed disparity in the prevalence in various metropolis [11-16]. Most of their reports attributed the $H$. pylori infections in children to poor socio- economic status, water sources, hygienic practices, overcrowding, and environments among others [17]. This study was conducted to determine the seroprevalence of Helicobacter pylori infection among children attending Public Hospitals in Keffi metropolis, Nasarawa state.

\section{Materials and Method}

The study was hospital based and was carried out in the two government owned hospitals; The Federal Medical Centre (FMC) and General Hospital both in Keffi Metropolis of Nasarawa state, Nigeria. The study population comprised of 100 children with different age groups between 0-15 years, who showed up at the paediatric outpatient department (POPD), Children emergency departments, Outpatients department and Emergency Units of the Hospital as well as those were at the laboratory for other investigations in both hospitals during the 3-month period of the research.

Prior to sample collection, an ethical clearance was obtained from the health research ethics committee of the Federal Medical Centre (FMC) and the General Hospital, Keffi. The ethical registration number is NHREC/21/12/2012.

Consent forms were also given out to parents or guardians of the children to obtain their consents and the details and relevance of the study were explained to them. A questionnaire was administered to the parents or guardians of the children to draw information about their ages, gender, presenting symptoms and other demographic characteristics like sharing of bedroom, drinking water source, type of toilet used and other hygienic practices.

The children's blood sample was collected via venipuncture. Afterwards, they were centrifuged at $3500 \mathrm{rpm}$ for 5 minutes to separate the serum from the red blood cells before they were serologically examined for $H$. pylori immunoglobulin-G antibodies using an immuno-chromatographic rapid test kits (Global).All laboratory techniques were duly observed, and the tests were carried out by strictly adhering to the manufacturer's instructions. Two distinct red lines on both control ' $C$ " and test ' $T$ ' region indicated a positive result while one line on the control ' $\mathrm{C}$ ' and non on the test ' $\mathrm{T}$ ' region indicates a negative result. No line on the Control ' $\mathrm{C}$ ' region would indicate an invalid result.

Data were summarized into tables. The seropositivity for H. pylori was computed according to age, gender and predisposing factors and was evaluated using Chi-square $\left(\chi^{2}\right)$ test by use of Smith Statistical Package (SSP) version 2.8. The statistical significance of the seropositive rates among comparison groups was also tested. P-value of $\leq 0.05$ was the significant level.

\section{Result Presentation and Data Analysis}

The overall prevalence of Helicobacter pylori infection among the 100 children who voluntarily participated in the research during the three-month period was $6.0 \%$.

Table 1 show that the prevalence was higher in the female participants $(7.1 \%)$ than in male $(4.6 \%)$. From the chi square $\left(\chi^{2}\right)$ analysis, the prevalence of $H$. pylori infection was insignificant $(\mathrm{P}>0.05)$ with respect to the gender of the children (Table 1).

\begin{tabular}{|c|c|c|c|}
\hline Gender & $\begin{array}{c}\text { Number of } \\
\text { Examined } \\
\text { sample }\end{array}$ & $\begin{array}{c}\text { Number } \\
\text { Seropositive }\end{array}$ & $\%$ \\
\hline Male & 44 & 2 & 4.6 \\
\hline Female & 56 & 4 & 7.1 \\
\hline Total & 100 & 6 & 6 \\
\hline \multicolumn{3}{|c}{ P-value $=0.7249$} \\
\hline
\end{tabular}

Table 1: Prevalence of $H$. pylori infection among children with respect to gender.

In Table 2 the prevalence of $H$. pylori infection was associated with the children's age. Although no statistical difference $(\mathrm{p}=0.4928)$ was observed, children of age group $12-15$ years had the highest prevalence of $30.8 \%$ while those whose ages fell between 0-3 years showed no infection. The table further reveals that the prevalence of $H$. pylori infection increases with increase in age of the children.

\begin{tabular}{|c|c|c|c|}
\hline Age & $\begin{array}{c}\text { Number of examined } \\
\text { sample }\end{array}$ & $\begin{array}{c}\text { Number } \\
\text { Seropositive }\end{array}$ & $\%$ \\
\hline $\mathbf{0 - 3}$ & 40 & - & - \\
\hline $\mathbf{4 - 7}$ & 29 & 1 & 3.5 \\
\hline $\mathbf{8 - 1 1}$ & 18 & 1 & 5.6 \\
\hline $\mathbf{1 2 - 1 5}$ & 13 & 4 & 30.8 \\
\hline Total & 100 & 6 & 6 \\
\hline \multicolumn{3}{|c|}{ P-value $=\mathbf{0 . 4 9 2 8}$} \\
\hline
\end{tabular}

Table 2: Prevalence of $H$. pylori infection among children with respect to their Age.

Furthermore, the prevalence of $H$. pylori infection was associated with the participants sociodemographic characteristics as shown in Table 3. The table shows that most of the children's parents were literate and had attended post-secondary school. The children whose fathers had attended only primary school had the highest prevalence of $20.0 \%$ followed by those whose father had only Primary education. Also, those whose parents had no formal education showed no infection. Statistically, there was no significant difference $(\mathrm{p}>0.05)$ in the prevalence of $H$. pylori among the children with respect to their Father's educational status. 


\begin{tabular}{|c|c|c|c|c|c|}
\hline Sociodemographic Characteristics & Number of samples examined & Numbers Seropositive & $(\%)$ & $\left(\chi^{2}\right)$ & P-Value \\
\hline \multicolumn{6}{|l|}{ Father's Educational Status } \\
\hline No formal education & 9 & - & - & \multirow{4}{*}{0.4444} & \multirow{4}{*}{0.9309} \\
\hline Primary School & 5 & 1 & 20 & & \\
\hline Secondary School & 30 & - & - & & \\
\hline Post-Secondary School & 56 & 5 & 8.9 & & \\
\hline \multicolumn{6}{|l|}{ Mother's Educational level } \\
\hline No formal education & 12 & - & - & \multirow{5}{*}{0.7944} & \multirow{5}{*}{0.8508} \\
\hline Primary School & 19 & 2 & 10.5 & & \\
\hline Secondary School & 33 & 1 & 3 & & \\
\hline Post-Secondary School & 36 & 3 & 8.3 & & \\
\hline \multicolumn{4}{|l|}{ Father's Occupation } & & \\
\hline Civil service & 37 & 3 & 8.1 & \multirow{5}{*}{0.5333} & \multirow{5}{*}{0.9702} \\
\hline Teaching & 15 & 1 & 6.7 & & \\
\hline Trading & 10 & 1 & 10 & & \\
\hline Farming & 12 & - & - & & \\
\hline Others & 26 & 1 & 3.8 & & \\
\hline \multicolumn{6}{|l|}{ Mother's Occupation } \\
\hline Civil Service & 10 & 1 & 10 & \multirow{6}{*}{1.9132} & \multirow{6}{*}{0.861} \\
\hline Teaching & 18 & 4 & 22.2 & & \\
\hline Trading & 30 & - & - & & \\
\hline Farming & 10 & - & - & & \\
\hline Homemaker & 10 & 1 & 10 & & \\
\hline Others & 12 & - & - & & \\
\hline \multicolumn{6}{|l|}{ Type of Housing Accommodation } \\
\hline A room Apartment & 40 & 2 & 5 & \multirow{4}{*}{0.0765} & \multirow{4}{*}{0.9945} \\
\hline Flat Apartment & 53 & 4 & 7.5 & & \\
\hline Duplex & 7 & - & - & & \\
\hline Others & - & - & - & & \\
\hline \multicolumn{6}{|l|}{$\begin{array}{c}\text { Number of people living in the } \\
\text { house }\end{array}$} \\
\hline $1-4$ & 36 & - & - & \multirow{3}{*}{1.0694} & \multirow{3}{*}{0.5858} \\
\hline $5-8$ & 48 & 6 & 12.5 & & \\
\hline 9-12 & 16 & - & - & & \\
\hline \multicolumn{6}{|l|}{$\begin{array}{c}\text { Number of persons sleeping in a } \\
\text { room }\end{array}$} \\
\hline $1-4$ & 80 & 3 & 3.8 & \multirow{3}{*}{1.5} & \multirow{3}{*}{0.4723} \\
\hline $5-8$ & 20 & 3 & 15 & & \\
\hline $9-12$ & - & - & - & & \\
\hline
\end{tabular}

Table 3: Prevalence of $H$. pylori infection among children with respect to other Socio-demographic Characteristics.

Likewise, there was no significant difference in the prevalence of $H$. pylori infection with respect to the children' mothers' level of education ( $p>0.05)$. As the table showed that the children whose mothers' educational status is primary school only, had the highest prevalence of $10.5 \%$ while those whose mothers had no formal education showed no infection. 
The table further reveals the prevalence of $H$. pylori infection with respect to the participants' fathers' occupation. Most of the participant's fathers worked in the civil service; those whose fathers' occupation is trading had the highest prevalence of $10.0 \%$ while those whose fathers are farmer showed no infection. The prevalence of $H$. pylori infection among the children with respect to their fathers' occupation was statistically insignificant $(\mathrm{p}>0.05)$. The prevalence of $H$. pylori infection to the children's mothers' occupation also showed no difference statistically $(p>0.05)$. The children whose mothers were teachers had the highest prevalence of
$22.2 \%$ while those whose occupation was farming, trading and other forms showed no infection.

The housing conditions of the children revealed that most of the infected participants were those who live in a flat apartment, with the highest prevalence of $7.5 \%$ while those who lived in duplex showed no infection. However, there was no significant difference $(\mathrm{p}>0.05)$ in the prevalence of $H$. pylori infection among the children in terms of their housing conditions. There was also no association between the number of persons living in a house ( $p>0.05)$ or persons sleeping in a room $(\mathrm{p}=0.4723)$ and the prevalence of $H$. pylori infection.

\begin{tabular}{|c|c|c|c|c|c|}
\hline Predisposing factors & $\begin{array}{c}\begin{array}{c}\text { Number of samples } \\
\text { examined }\end{array} \\
\end{array}$ & $\begin{array}{c}\text { Numbers } \\
\text { Seropositive } \\
\end{array}$ & $(\%)$ & $\left(\chi^{2}\right)$ & P-Value \\
\hline \multicolumn{6}{|l|}{ Source of drinking water } \\
\hline Well & 8 & - & - & \multirow{4}{*}{1.3390} & \multirow{4}{*}{0.9875} \\
\hline Borehole & 47 & 3 & 6.4 & & \\
\hline Tap & 21 & - & - & & \\
\hline Others & 24 & 3 & 12.5 & & \\
\hline \multicolumn{6}{|l|}{ Type of Toilet } \\
\hline Pit & 17 & 2 & 11.7 & \multirow{3}{*}{0.6667} & \multirow{3}{*}{0.7165} \\
\hline Water closet & 44 & 3 & 6.8 & & \\
\hline Others & 39 & 1 & 2.5 & & \\
\hline \multicolumn{6}{|c|}{ Clean up behaviour after defecation } \\
\hline Water & 80 & 5 & 5.9 & \multirow{4}{*}{0.0000} & \multirow{4}{*}{1.0000} \\
\hline Tissue paper & 10 & 1 & 7.7 & & \\
\hline Scrap paper & - & - & - & & \\
\hline Others & 10 & - & - & & \\
\hline \multicolumn{6}{|c|}{ Hand wash after defecation } \\
\hline Yes & 68 & 5 & 7.4 & \multirow[t]{2}{*}{0.4444} & \multirow[t]{2}{*}{0.5049} \\
\hline No & 32 & 1 & 3.1 & & \\
\hline \multicolumn{6}{|c|}{ Hand washing behaviour after defecation } \\
\hline Water and soap & 44 & 5 & 11.4 & \multirow[b]{2}{*}{0.7609} & \multirow[b]{2}{*}{0.6835} \\
\hline Water only & 24 & - & - & & \\
\hline \multicolumn{6}{|l|}{ Eating Habit } \\
\hline Once & - & - & - & \multirow{4}{*}{0.0843} & \multirow{4}{*}{0.9936} \\
\hline Twice & - & - & - & & \\
\hline Thrice & 43 & 3 & 7.0 & & \\
\hline Others & 57 & 3 & 5.3 & & \\
\hline \multicolumn{6}{|l|}{ Like Peppery foods } \\
\hline Yes & 53 & 4 & 7.5 & \multirow[b]{2}{*}{0.3429} & \multirow[b]{2}{*}{0.5581} \\
\hline No & 47 & 2 & 4.3 & & \\
\hline \multicolumn{6}{|l|}{ Eat peppery foods } \\
\hline Yes & 67 & 4 & 6.0 & \multirow[t]{2}{*}{0.0000} & \multirow[t]{2}{*}{1.0000} \\
\hline No & 33 & 2 & 6.1 & & \\
\hline
\end{tabular}

Table 4: Prevalence of $H$. pylori infection among children with respect to other Predisposing factors. 
The prevalence of $H$. pylori was also compared to other predisposing factors as shown in Table 4. And it shows that $5 \%$ of the subjects who were positive for $H$. pylori infection practiced hand washing with soap and water after defecation and about half of those positive used water closet. However, that there was no significant difference between source of drinking water $(p=0.9875)$, type of toilet $(p=0.7165)$, clean-up behavior after toilet $(\mathrm{p}=1.0000))$, hand wash after toilet (0.5049), and eating habits $(\mathrm{p}=0.9936)$ among others with the prevalence of $H$. pylori infection.

\begin{tabular}{|c|c|c|c|}
\hline & $\begin{array}{c}\text { Number of } \\
\text { samples } \\
\text { examined }\end{array}$ & $\begin{array}{c}\text { Numbers } \\
\text { Seropositive }\end{array}$ & $\%$ \\
\hline Asymptomatic & 93 & 5 & 5.4 \\
\hline Symptomatic & 7 & 1 & 14.3 \\
\hline Total & 100 & 6 & 6 \\
\hline \multicolumn{3}{|c}{$\mathbf{P = 0 . 9 0 5 6}$} \\
\hline
\end{tabular}

Table 5: Comparison of $H$. pylori infections between symptomatic and asymptomatic children attending selected hospitals in Keffi.

\section{Discussion}

Helicobacter pylori infection is the most common chronic human bacterial infections associated with gastro-duodenal disease. It has been reported to have colonized about $50 \%$ of adults who might have acquired the infection in their childhood [18]. Several predisposing factors have been associated with the prevalence of $H$. pylori infection in developing countries $[14,19]$.

From this study, the prevalence of Helicobacter pylori infection among the randomly selected children used for the study was $6.0 \%$. This is a low prevalence rate and suggests that Helicobacter pylori infection is insignificant in the children age group of the study locality. This is inconsistent with the high prevalence rates previously reported among children in Nigeria and some other developing countries [2022]. However, the result agrees that the prevalence of $H$. pylori infections varies between and within countries as reported by Alemayehu [23].

The prevalence of Helicobacter pylori infection was studied with respect to age, gender and other demographic characteristics and predisposing factors. There was also comparison between symptomatic and asymptomatic children. Its prevalence with respect to gender was higher in female $(7.1 \%)$ than in male $(4.6 \%)$. Statistically, there was no significant difference in the prevalence of Helicobacter pylori infection with respect to gender, this can be compared to a study by Mynepalli [16].

However, in the prevalence of Helicobacter pylori infection with respect to age, the highest prevalence was observed among children of ages 12-15 (30.8\%) and the lowest prevalence was among children of ages 4-7 (3.5\%), while those with ages 0-3 showed no infection. This agreed with previous reports that the prevalence of Helicobacter pylori infection increases with increase in age of children. There was no Statistical difference $(\mathrm{p}>0.05)$ in the prevalence of Helicobacter pylori infection with respect to the age of the children. This can be compared to a study by Mynepalli et al in 2014 [16], who noted a high proportion of infection in people of 15 years and above than those less than 14 years with no significant difference. This is unlike a similar study in Uyo [21] that recorded highest prevalence in children of 1-5 years age group and a lower prevalence rate among children of ages 11-15years. On the contrary, Daniyan found age to be statistically significantly associated with $H$. pylori seropositivity with the highest prevalence in children aged between 6-12 years followed by children aged 1 to 5 years [13].

Data from this study did not show significant association between socio-demographic characteristics and prevalence of H. pylori infection. Hence, it indicates that the respondent's fathers' and mothers' educational status and occupation did not show any significant difference on the prevalence of $H$. pylori infection and therefore had no influence on the $H$. pylori seropositivity of the children as agreed by Mynepalli et al., 2014.In contrast, Remi and colleagues suggested that the prevalence of the infection may be associated with standard of living [24].

Slightly more than half $(7.5 \%)$ of those infected with $H$. pylori lived in a flat apartment, although with no significant difference $(p=0.9945)$. Hence, it can be deduced from the findings that neither living in a room apartment nor flat had influence on the prevalence of $H$. pylori infection among the study population. There is a possibility that overcrowded households increase the seropositivity of its members [24, 25]. However, in this study, $16 \%$ of the children were living in a house with about 9-12 occupants and none of the children in this category was positive for $H$. pylori infection. Only those with 5-8 persons living in the same home were positive $(12.5 \%)$. Nonetheless, this result was not enough to associate the living conditions of the subjects with $H$. pylori infection.

Information on predisposing factors like drinking water, type of toilet, clean-up behavior after toilet, hand wash after toilet, eating habits among others, provided no significant association with the prevalence of $H$. pylori infection. This might be as a result of increased awareness about hygienic practices even among those who tested positive to $H$. pylori [16].

There was also no significant difference in the comparison of the prevalence of $\mathrm{H}$. pylori infection between symptomatic and asymptomatic children.

\section{Conclusion}

The IgG seropositivity of $H$. pylori infection in this study was low with a prevalence rate of $6.0 \%$ and showed no distinct association with age, gender, sociodemographic characteristics, predisposing factors and perceived symptoms 
among the children who participated in the study. High proportion of the children lived in flat apartment, drank borehole water, ate thrice a day, and observed hand wash after defecation using soap and water yet, no association existed between these factors and $H$. pylori infection. However, this does not eliminate the fact that $H$. pylori infection exists among children in the age population studied. Therefore, other risks factor not examined may have been responsible for seropositivity to the $H$. pylori infection.

\section{Competing Interests}

Authors have declared that no competing interests exist.

\section{Acknowledgement}

We wish to thank all the children and their parents/guardians who participated, for their excellent cooperation, the Management and Staff of both the Federal Medical Center and General Hospital of Nasarawa State Keffi for allowing access to their facilities and patients.

\section{References}

1. Marshall B, Warren JR (1984) Unidentified curved bacilli in the stomach of patients with gastritis and peptic ulceration. The Lancet, 323: 1311-1315.

2. Hunt RH, Xiao SD, Megraud F, Leon-Barua R, Bazzoli F, Van der Merwe S, et al. (2011). Helicobacter pylori in developing countries. World gastroenterology organisation global guideline. Journal of Gastrointestinal and Liver Diseases 20: 299-304.

3. Sýkora J, Rowland M (2011) Helicobacter pylori in Pediatrics. Helicobacter 16: 59-64.

4. IARC Working Group on the Evaluation of Carcinogenic Risks to Humans. (1994). Lyon, 7-14 June 1994. Schistosomes, liver flukes, and Helicobacter pylori. IARC Monographs on the Evaluation of Carcinogenic Risks to Humans 61:1-241.

5. Eslick GD (2006) Helicobacter pylori infection causes gastric cancer A? Review of the epidemiological, metaanalytic, and experimental evidence. World journal of gastroenterology: WJG 12: 2991-2999.

6. De Reuse H, Vinella D, Cavazza C (2013) Common themes and unique proteins for the uptake and trafficking of nickel, a metal essential for the virulence of Helicobacter pylori. Frontiers in Cellular and Infection Microbiology 3: 94.

7. Wroblewski LE, Peek RM, Wilson KT (2010) Helicobacter pylori and gastric cancer: Factors that modulate disease risk. Clinical Microbiology Reviews 23: 713-739.

8. Thomas JE, Dale A, Bunn J, Harding M, Coward WA, et al. (2004) Early Helicobacter pylori colonization: The association with growth faltering in the Gambia. Archives of Disease in Childhood 89: 1149-1154.

9. Aziz RK, Khalifa MM, Sharaf RR (2015) Contaminated water as a source of Helicobacter pylori infection: A review. Journal of Advanced Research 6: 539-547.
10. Ishaleku D, Ihiabe HA (2010) Seroprevalence of Helicobacter pylori infection among students of a Nigerian University. Asian Pacific Journal of Tropical Medicine 3: 584-585.

11. Ajayi EO (2015) The Prevalence of Helicobacter pylori infection Using Stool Antigen in Apparently Healthy Nigerian Secondary School Children in Surulere LGA, Lagos State. Faculty of PAEDIATRICS.

12. Aitila $P$, Mutyaba $M$, Okeny $S$, Ndawula Kasule M, Kasule R, et al. (2019) Prevalence and risk factors of Helicobacter pylori infection among children aged 1 to 15 years at Holy Innocents'Children's hospital, Mbarara, South Western Uganda. Journal of tropical medicine 2019.

13. Olapeju DW, Chidozie IB, Thecla EC, Onyinye AU, Obumneme EB, et al. (2020) Seroprevalence and Risk Factors of Helicobacter pylori Infection Among Children in South-East Nigeria. Journal of Gastroenterology and Hepatology Research 9: 3066-3070.

14. Etukudo OM, Ikpeme EE, Ekanem EE (2012) Seroepidemiology of Helicobacter pylori infection among children seen in a tertiary hospital in Uyo, Southern Nigeria. Pan African Medical Journal 12: 39.

15. Msekandiana A, Msuya L, Philemon R, M'mbaga B, Kinabo G (2019) Seroprevalence, risk factors and comorbidities associated with Helicoibacter pylori infection amongst children receiving care at Kilimanjaro Christian Medical Center. Afri Health Sci 19: 3208-3216.

16. Mynepalli SKC, Maureen O, Mumuni A (2014) Prevalence of helicobacter pylori and hygiene practices among public secondary school students in Ikeja local government area, Lagos, Nigeria. Health 6: 250-258.

17. Asrat D, Nilsson I, Mengistu Y, Ashenafi S, Ayenew K, et al (2004) Prevalence of Helicobacter pylori infection among adult dyspeptic patients in Ethiopia. Annals of Tropical Medicine \& Parasitology 98: 181-189.

18. Crew KD, Neugut AI (2006) Epidemiology of gastric cancer. World Journal of Gastroenterology. 12:354-362.

19. Senbanjo IO, Oshikoya KA, Njokanma OF (2014) Helicobacter pylori associated with breastfeeding, nutritional status and recurrent abdominal pain in healthy Nigerian children. The Journal of Infection in Developing Countries 8: 448-453.

20. Babatola AO, Akinbami FO, Adeodu OO, Ojo TO, Efere MO, et al. (2019) Seroprevalence and determinants of Helicobacter pylori infection among asymptomatic underfive children at a tertiary hospital in the south-western region of Nigeria. African Health Sciences 19: 20822090.

21. Ikpeme EE, Etukudo OM, Ekanem EE (2013) Clinical correlates of Helicobacter pylori infection in children seen at a tertiary hospital in Uyo, Southern Nigeria. Nigerian Journal of Paediatrics, 40: 45-49.

22. Langat AC, Ogutu E, Kamenwa R, Simiyu DE (2006) Prevalence of Helicobacter pylori in children less than three years of age in health facilities in Nairobi province. East African Medical Journal 83: 471: 477.

23. Alemayehu A (2011) Seroprevalence of helicobacter pylori infection and its risk factors among adult patients with dyspepsia in Hawassa Teaching and Referral 
Hospital, South Ethiopia. Addis Ababa University, Ethiopia.

24. Remi Q, Olufemi FO, Odedara OO, Bamiro SA (2015) Seroprevalence of Helicobacter pylori infection among asymptomatic children in Lagos, Nigeria. Journal of Advances in Medicine and Medical Research 1-7.
25. Perry S, De La Luz Sanchez M, Yang S, Haggerty TD, Hurst P, Perez-Perez G, et al. (2006). Gastroenteritis and transmission of Helicobacterpylori infection in households. Emerging Infectious Diseases 12: 1701-1708.

Citation: Adedoyin JJ, Ishaleku D (2020) Seroprevalence of Helicobacter pylori infection among Children attending selected Hospitals in Keffi, Nigeria. Adv Pub Health Com Trop Med: APCTM-120. 